\title{
Does Summer Range Quality Influence Sex Ratios among Mule Deer Fawns in Utah?
}

\author{
JORDAN C. PEDERSON AND K.T. HARPER
}

\begin{abstract}
Larger ratios of males to females were found among fawns from herd units where forage production on the summer ranges was low and the forage base was dominated by browse. Summer ranges where forage production was high and dominated by forbs produced even or female dominated sex ratios. The number of deer harvested per unit area was correlated with sex ratio of the fawn crop: harvests were lower where males were significantly overrepresented in the fawn crop and higher where sex ratios were even or female biased.
\end{abstract}

We previously reported the comparative productivity of mule deer on 2 southeastern Utah mountains that differed markedly in summer range condition but had winter ranges of comparable quality (Pederson and Harper 1978, 1979). The La Sal Mountain mule deer herd was shown to consistently produce about $40 \%$ more fawns per doe than the Henry Mountain herd. Deer from the La Sals were also larger than animals of the same age and sex from the Henrys (Pederson and Harper 1978). We could detect no difference in either disease incidence or predation between the 2 herds, but the La Sal Mountain summer range was in good to excellent condition, and the forage base for deer was dominated by forbs. In contrast, the Henry Mountains summer range was in poor to fair condition, and the forage base was heavily dominated by shrubs (Pederson and Harper 1978).

Since considerable evidence suggests that nutrition may influence the sex ratio of offspring born to a variety of cervid (deer) species (Julander et al. 1961; Verme 1965, 1967, 1969; Bannikov 1967; Robinette et al. 1973, 1977; McCullough 1979), we expanded our previous study to include a comparison of sex ratios in mule deer herds on 7 ranges known to vary among themselves in respect to vegetative condition.

Sex ratio statistics have many implications for management. Medin and Anderson (1979) found that a 4\% shift toward females in the ratio resulted in a $16 \%$ increase in fawn production. If range condition can be shown to be correlated with herd sex ratios, managers may be able to manipulate sex ratios through management of the forage base. Managers may also be better able to anticipate herd growth potential and prescribe more suitable management and harvest programs through a knowledge of range conditions coupled with inexpensive demographic studies.

\footnotetext{
Authors are regional game manager, Utah Division of Wildlife Resources, Springville, Utah 84663 ; and professor of botany and range science, Brigham Young University, Provo, Utah 84602 .

Data for this paper were collected in connection with Utah Federal Aid to Wildlife Restoration Project W-65-R. The authors extend their thanks and appreciation to James W. Bates, Norman J. Bowden, Floyd H. Coles, Norman V. Hancock, Rodney T. John, Jim Karpowitz, Bob J. Nielson, and Homer D. Stapley of the Utah Division of Wildlife Resources. We also acknowledge the help of Bruce L. Welch and Susan

White of the U.S. Forest Service, Intermountain Forest and Range Experiment Station, for their help and the use of their laboratory facilities. Hal L. Black, Jerran T. Flinders and Clyde L. Pritchett, Brigham Young University, provided suggestions and helpful reviews.

Manuscript received August 2, 1982.
}

\section{Methods}

Our research design required that both deer harvest and forage data be available for each deer herd unit included in the study. The analysis of $141,458 \mathrm{~m}^{2}$ of vegetation transects provided the forage production and composition data for our study. Sex of fawns was determined by game biologists. Only samples that included at least 60 sexed fawns per herd unit were used. Herd units where deer winter range had been significantly reduced by encroachment of agricultural or urban developments were excluded from consideration. Estimates of weighted average forage production across entire herd units required knowled ge of areal extent of each vegetational type as well as annual production and relative contribution of shrub, grass, and forb tissue in that vegetation type.

Offspring sex ratios were obtained in a period when it was legal for hunters to harvest fawns of the year. Even with either sex harvests, there may be a bias toward the harvest of males (Robinette et al. 1977). Accordingly, the sex ratios reported here may be slightly biased in favor of males, but we assume the bias to be uniform among herd units. Animals were aged using the tooth replacement and wear technique (Robinette et al. 1957).

Since buck-only hunts were initiated in management of some mule deer herds in Utah in 1973, we confined our analysis to records from the $1966-72$ period. A total of 106,582 deer including 3,226 fawns were harvested from the units selected. Basic demographic data were drawn from the annual Utah Big Game Investigations and Recommendation Reports published by the Utah Division of Wildlife Resources (Stapley 1969, John 1978). Vegetational data were taken from reports by Coles and Pederson (1969), King and Olsen (1972), and Giunta (1979). All preseason doe-fawn counts were based on samples of $200+$ animals.

Preliminary analysis and prior work (Pederson and Harper 1978) showed summer range conditions were more closely correlated with herd productivity parameters than were conditions on winter ranges on the herd units selected for analysis. Accordingly, our investigations here utilize summer range parameters [area of vegetation types, average forage production, relative contribution of shrubs (leaves and twigs), grasses and forbs to the forage crop, and deer harvest stated in terms of animals per unit area of summer range].

In order to compare the over-all environment associated with the 7 herd units, we considered elevation, average precipitation, and geological parent materials as possible influencers of herd production. Maximum elevation on each area was taken from U.S. Geological Survey maps. Precipitation estimates for each herd unit were taken from a U.S. Department of Commerce map (State of Utah Normal Annual Precipitation, 1931-1960). Herd unit boundaries for each unit in the study were drawn on the precipitation map, and area in each precipitation zone was determined. Soil parent material was determined from a geological map (Hintze 1975). Herd unit boundaries were again drawn on the map, and 
Table 1. Average characteristics of seven mule deer herds in Utah during 1966-72. Harvest per unit area considers the area of summer range only.

\begin{tabular}{|c|c|c|c|c|c|}
\hline Herd name & $\begin{array}{c}\text { Ave. no. deer } \\
\text { harvested per year }\end{array}$ & $\begin{array}{c}\text { Total no. } \\
\text { fawns sexed }\end{array}$ & $\begin{array}{l}\text { Ave No. deer harvested } \\
\text { per } \mathrm{km}^{2} / \text { year }\end{array}$ & $\begin{array}{l}\text { Ratio of males/female } \\
\text { in the fawn harvest }\end{array}$ & $\begin{array}{c}\text { Fawns } / 100 \text { does in pre- } \\
\text { season counts }\end{array}$ \\
\hline $\begin{array}{l}\text { Avintaquin } \\
\text { Currant Cr. } \\
\text { N. Book Cliffs } \\
\text { LaSal Mts. } \\
\text { San Juan-Blue Mts. } \\
\text { San Juan-Elk Ridge } \\
\text { Pine Valley Mts. }\end{array}$ & $\begin{array}{r}1,226 \\
4,129 \\
1,153 \\
2,663 \\
3,397 \\
1,867 \\
791\end{array}$ & $\begin{array}{r}138 \\
1,660 \\
121 \\
356 \\
648 \\
243 \\
60\end{array}$ & $\begin{array}{l}1.05 \\
1.95 \\
2.02 \\
5.48 \\
8.56 \\
3.70 \\
2.63\end{array}$ & $\begin{array}{l}1.12 \\
2.03^{*} \\
2.10^{*} \\
0.95 \\
0.68^{*} \\
0.80 \\
1.00\end{array}$ & $\begin{array}{l}78 \\
95 \\
76 \\
91 \\
94 \\
79 \\
85\end{array}$ \\
\hline
\end{tabular}

"Astersiked ratios differ significantly from 1.0 as shown by Chi-square analysis of actual numbers of animals of each sex.

predominant parent materials were determined for each unit.

Variations in fawn/sex ratios and other population parameters were correlated with range condition parameters (total annual forage production and composition) on the individual herd units using simple correlation procedures (Snedecor and Cochran 1967).

\section{Results}

Sex ratios among fawns harvested in October during the years 1966-72 differed significantly from unity in 3 of the 7 herds (Table 1). It is assumed the sex ratio of harvested fawns was representative of all fawns surviving to mid-October in the herd units considered during the 1966-72 period. Sex ratios (males/females) ranged from 0.68 to 2.10 among the herds. The fawn sex ratio for the San Juan-Blue Mountains herd was significantly less than 1.0 (females exceeded males), while 2 other herds (Currant Creek and North Book Cliffs) had significantly more male fawns than would have been expected assuming a $1: 1$ sex ratio. Such results suggest that local habitat conditions have exerted a significant influence on the sex ratio of some herds.

In order to test the hypothesis that food availability exerted a significant effect on fawn sex ratios, data on annual forage production were correlated with sex ratios and composition on the herd units considered (Table 2). Two additional population parameters (animals harvested per unit area and fawns per doe; Table 1) that were likely to be affected by habitat quality were also correlated with forage variables. There latter tests were designed as further checks on the assumption that amount and composition of forage on a herd unit did affect deer reproductive performance. The herd units varied widely in respect to both deer harvested per unit area (range of 1.05 to $8.56 \mathrm{deer} / \mathrm{yr} / \mathrm{km}^{2}$ of summer range) and fawns per 100 does (range from 76.1 to 95.3 fawns/ 100 does).

Analysis showed that both amount of forage and composition of forage were significantly correlated with sex ratios. Less productive ranges produced more male than female fawns, while the reverse was true on more productive ranges $(r=.85)$. Likewise, ranges where forbs were not an important component of the vegetation generated more males than females in the fawn crop, but ranges where forbs were abundant produced balanced sex ratios or significantly more females than males ( $r=.79$ when the logarithm of percent forbs was evaluated as the independent variable). The logarithm to base 10 transformation of percent forbs in the forage crop was more strongly correlated with herd productivity and sex ratio than was percent composition of forbs per se, since the untransformed relationship was nonlinear. Geological parent material, elevation, and weighted average precipitation were not significantly correlated with number of animals harvested per unit area or the proportion of males and females in the fawn crops.

Total forage production and percent of total production contributed by forbs were also significantly correlated with herd productivity as indicated by October fawn:doe ratios. In addition, forage production and relative contribution of forbs were positively correlated with the number of fawns/100 does (pre-hunt counts), but those relationships were not statistically significant. The proportion of shrub tissue in the forage base was negatively correlated with herd productivity and positively correlated with sex ratio among fawns, but the relationships were not significant $(P \leq .10, P \leq .05)$. The proportion of grass in summer forage did not appear to be related to either herd productivity or sex ratio.

\section{Discussion}

These data support the hypothesis that summer range forage conditions influence sex ratios among fawns of the year. Since ranges that produced more male than female fawns also showed low deer harvest rates and smaller numbers of fawns per doe (Table 1), we conclude that range condition was lower on these ranges than on ranges where sex ratios were even or females out numbered males. In this study the more productive summer ranges (usually at higher elevations in Utah) produced more female than male fawns. The forage base of such rangs included over $25 \%$ forbs by weight.

The literature suggests forbs are both richer in protein and phosphorus and more digestible by herbivores than either grasses or shrubs (Nordan et al. 1968, Torgerson and Pfander 1971, Short 1971, Urness 1973, Snider and Asplund 1974, Wallmo et al. 1977, Tueller 1979). In respect to both tissue chemistry and digestibility, the foregoing references show grasses resemble forbs more closely than shrubs. In that context, it is of interest that in this study, herd

Table 2. Characteristics of ranges associated with the mule deer herds considered. Forage composition is based on weight for all Units except Avintaquin where plant cover but not weight data were available. All forage values are weighted averages for all vegetation types on a herd unit.

\begin{tabular}{lccccc}
\hline \hline Herd unit name & $\begin{array}{c}\text { Maximum elevation } \\
(\mathrm{m})\end{array}$ & $\begin{array}{c}\text { Total annual above } \\
\text { ground forage } \\
\text { production } \mathrm{kg} / \mathrm{ha}\end{array}$ & Shrubs & Forbs & Gomposition of the Forage (\%) \\
\hline Avintaquin & 2,819 & $\mathrm{NA1}$ & 49 & 16 & 35 \\
Currant Cr. & 3,488 & 1,042 & 51 & 13 & 36 \\
N. Book Cliff & 2,536 & 714 & 68 & 14 & 18 \\
LaSal Mts. & 3,877 & 1,413 & 18 & 58 & 24 \\
San Juan-Blue Mts. & 3,463 & 1,829 & 38 & 36 & 32 \\
San Juan-Elk Ridge & 2,761 & 1,210 & 37 & 28 & 9 \\
Pine Valley Mts. & 3,147 & 1,501 & 63 & 28 & 9 \\
\hline
\end{tabular}

INA=not available. 
productivity (harvest/ unit area and fawns/100 does) declincd and sex ratio (males/female) among fawns increased as shrubs increased proportionally in the forage crop. Differences in protein content and digestibility between shrubs and forbs may explain the disparate effects those groups of plants seemed to exert on deer populations in this study.

Although the summer ranges we studied seemed to exert a stronger influence on mule deer population dynamics than winter ranges in this study, the reverse is undoubtedly true for many other herds in the West (Wallmo 1981). In Utah, herd units in northern Utah are especially likely to be winter range limited.

Our data are inadequate to conclusively demonstrate that range quality alters sex ratio among deer offspring, but the results are strong enough to justify further work. In Utah, several ranges that once supported large mule deer herds have experienced precipitous declines in deer numbers in the past $\mathbf{4 0}$ years. Those herds now show little tendency to increase even in the absence of hunting. In all cases, those herds are on ranges that appear to have had a major decline in range condition such that unpalatable shrubs have increased and palatable grasses and forbs have decreased. In the only case in which such a herd has been studied carefully over an extended time period, there appears to have been a gradual increase in the male-to-female ratio among fawns (Robinette et al. 1977). Our ability to successfully manage such herds would be greatly improved if we definitely knew whether range condition could alter the sex ratio of the fawn crop.

\section{Literature Cited}

Bannikov, A.G. 1967. Moose in the USSR and its explanation. Int. Congr. Game Biologists (Aug. 22-27, Helsinki) V111:273-276.

Coles, F.C. and J.C. Pederson. 1969. Big game range inventory, 1967-68. Utah Div. of Wildl. Resources, Federal Aid Project W-65-R-16, Pub. No. 69-2.

Giunta, B.C. 1979. Big game range inventory, 1977. Utah Div. of Wild!. Resources, Federal Aid Project W-65-R-D-26, Job No. A-6, Pub. No. 79-3.

Hintze, L.F. 1975. Utah Geological Highway Map. Dep. of Geology. Brigham Young Univ. Spec. Pub. 3. Provo, Utah 84602.

John, R.T. 1978. Utah big game investigations and management recommendations, 1977-1978. Utah State Div. of Wildl. Resources Pub. No. 78-3.

Julander, O., W.L. Robinette, and D.A. Jones. 1961. Relation of summer range condition to mule deer herd productivity. J. Wildl. Manage. 25:54-60.

King, S. and B. Olsen. 1972. Big game range inventory, 1970-71. Utah Div. of Wildl. Resources, Federal Aid Project W-65-R-20, Pub. No. 72-10.
McCullough, D.R. 1979. The George Reserve deer herd. The University of Michigan Press, Ann Arbor.

Medin, D.E., and A.E. Anderson. 1979. Modeling the dynamics of a Colorado mule deer population. Wildl. Monogr. No. 68.

Nordan, H.C., I.M. Cowan, and A.J. Wood. 1968. Nutritional requirements and growth of blacktail deer, Odocoileus hemionus colubmainus, in captivity, p. 89-96. In: Comparative nutrition of wild animals. M.A. Crawford, Ed. Symp. Zoo. Soc. London, Academic Press, New York.

Pederson, J.C., and K.T. Harper. 1978. Factors influencing productivity of two mule deer herds in Utah. J. Range Manage. 31:105-110.

Pederson, J.C., and K.T. Harper. 1979. Chemical composition of some important plants of southeastern Utah summer ranges related to mule deer reproduction. Great Basin Nat. 39:122-128.

Robinette, W.L., D.A. Jones, G. Rogers and J.S. Gashwiler. 1957. Notes of tooth development and wear for Rocky Mountain mule deer. J. Wildl. Manage. 21:134-153.

Robinette, W.L., C.H. Brer, R.E. Pillmore, and C.E. Knittle. 1973. Effects of nutritional change on captive mule deer. J. Wildl. Manage. 37:312-326.

Robinette, W.L., N.V. Hancock and D.A. Jones. 1977. The Oak Creek mule deer herd in Utah. Utah State Div. of Wildl. Res. Pub. No. 77-15.

Short, H.L. 1971. Forage digestibility and diet of deer on southern upland range. J. Wildl. Manage. 35:698-706.

Snedecor, G.W., and W.G. Cochran. 1967. Statistical methods, 6th ed. The Iowa State Press, Ames.

Snider, C.C. and J.M. Asplund. 1974. In vitro digestibility of deer foods from the Missouri Ozarks. J. Wildl. Manage. 38:20-31.

Stapley, H.D. 1969. Utah big game investigations and management recommendations, 1968-1969. Utah State Div. of Fish and Game Pub. No. 69-5.

Torgerson, O., and W.H. Pfander. 1971. Cellulose digestibility and chemical composition of Missouri deer foods. J. Wildl. Manage. 35:121-131.

Tueller, P.T. 1979. Food habits and nutrition of mule deer on Nevada ranges. Nevada Dep. of Fish and Game, Reno. Final Report. Fed. Aid in Wild. Rest. Proj. W-48-5, Study 1, Job. 2.

Urness, P.J.1973. Deer nutrition in Arizona chaparral and desert habitats. Part II: chemical analyses and in vitro digestibility of seasonal deer forages. Arizona Fish and Game Dep., Special Report No. 3:39-52.

U.S. Department of Commerce. State of Utah - normal annual , 1931-1960. Map WR-1210-A. Weather Bureau, Fed. Bldg., Salt Lake City, Utah.

Verme, L.J. 1965. Reproduction studies on penned whitetail deer. J. WildI. Manage. 29:74-79.

Verme, L.J. 1967. Influence of experimental diets on whitetail deer reproduction. Trans. N. Amer. Wildl. and Nat. Res. Conf. 32:405-420.

Verme, L.J. 1969. Reproductive patterns of whitetail deer related to nutritional plane. J. Wildl. Manage. 33:881-887.

Wallmo, O.C., L.H. Carpenter, W.L. Regelin, R.B. Gill, and D.L. Baker. 1977. Evaluation of deer habitat on a nutritional basis. J. Range Manage. 30:122-127.

Wallmo, O.C. ed. 1981. Mule and black-tailed deer of North America. University of Nebraska Press, Lincoln. 